\title{
Development of Surgical Therapy of Epilepsy at the Montreal Neurological Institute
}

\author{
William Feindel
}

\begin{abstract}
Wilder Penfield's development of surgical methods for treating focal cerebral seizures, beginning with his early work in Montreal in 1928, is reviewed. The reliance on seizure pattern and focal brain pathology was enormously enhanced by the advent of EEG and direct electrical recording from the cortex during surgery. The recognition in the early 1950's of mesial temporal structures in the pathogenesis of temporal lobe epilepsy with automatism lead to more rational and successful surgical treatment. Positron emission tomography and especially magnetic resonance imaging have recently added to the essential diagnostic information of focal epilepsy provided by EEG.
\end{abstract}

RÉSUMÉ: Développement du traitement chirurgical de l'épilepsie à l'institut neurologique de Montréal. Nous revoyons la mise au point, par Wilder Penfield, de techniques chirurgicales pour le traitement des crises épileptiques focales, en commençant par ses premiers travaux à Montréal en 1928. L'emphase placée sur le pattern des crises et sur les lésions pathologiques focales du cerveau a été grandement rehaussée par l'avènement de l'électroencéphalographie et de l'enregistrement peropératoire direct de l'activité électrique de cortex. L'identification, au début des années cinquante, du rôle des structures mésiales du lobe temporal dans la pathogenèse de l'épilepsie temporale a mené à une approche chirurgicale plus rationnelle et plus efficace de ce problème. Plus récemment, la tomographie par émission de positons et particulièrement la résonance magnétique sont venues s'ajouter aux données, toujours essentielles, fornies par l'électroencéphalographie dans les cas d'épilepsie focale.

Can.J. Neurol. Sci. 1991; 18:549-553

\section{An early temporal lobectomy}

Wilder Penfield's first operation in Montreal for focal epilepsy was in November 1928 at the Royal Victoria Hospital. The young patient (RM) had fallen from a horse ten years before and required surgery for a right-sided subdural hematoma and brain contusion. He developed seizures with increasing frequency, up to 5 to 20 a day.

Eventually, this complex post-traumatic epileptogenic lesion required three operations in order to control these intractable seizures. Stanley Cobb and William Lennox came from Boston as consultants. At the first procedure, a small area of cortex was excised near the motor strip that was defined by stimulation. His attacks continued. A second exploratory craniotomy followed a few months later to expose the frontal lobe on the opposite side; no abnormalities were found so no removal of any sort was made.!

Penfield's sketch of the third and final operation, three years later, showed the sites of the stimulation responses and the thin scarred cortex of the temporal area which was widely resected (Figure 1).
Penfield referred to this as his first temporal lobectomy for seizures. He had applied the stimulation and excision techniques learned in the Breslau surgical clinic of Otfrid Forester during a six months' study leave before coming to Montreal. ${ }^{1}$ In the first few years after operation, the patient had a greatly reduced number of seizures. After he was given dilantin in 1939, the number of his attacks was reduced to 4 in the next 13 years.

In 1930, four years before the Institute opened, Penfield listed the neurosurgical cases at the Royal Victoria Hospital. ${ }^{2}$ Among the 325 operations carried out by the two neurosurgeons, Wilder Penfield and William Cone (Figure 2), there were fourteen examples of surgery for focal epilepsy. Despite these committed surgical duties, Penfield was able to edit for publication in 1932 a three volume multi-authored work, "Cytology and Cellular Pathology of the Nervous System", ${ }^{3}$ destined to become a neurological classic.

\section{A vascular mechanism for epilepsy}

Meanwhile, because stimulation of epicerebral blood vessels at operation was followed by local arterial constriction and

\footnotetext{
${ }^{1}$ In a letter years later to Herbert Jasper about this negative procedure obviously not rewarding for patient or surgeon, Penfield wrote, "You see, one can go wrong even without help of EEG."
}

From the Montreal Neurological Institute and Hospital, Department of Neurology and Neurosurgery, McGill University, Montreal Reprint requests to: Dr. William Feindel, Montreal Neurological Institute, Suite 110, 3801 University Street, Montreal, Quebec, Canada H3B 2B4 
sometimes by focal attacks (as in patient RM), Penfield had proposed the idea of a cerebral vascular mechanism in epilepsy. ${ }^{4}$ Herbert Jasper discussed with Penfield before coming to Montreal the use of new techniques for measuring cortical blood flow during operation. Penfield continued to follow this concept throughout his career; 5 in his last reference to this topic he noted the need to understand better these intriguing ictal changes in cortical blood flow. 6

\section{Cortical stimulation - the homunculus}

In another important publication in 1937, Penfield with Edwin Boldrey in "Brain"7 reviewed 163 patients operated upon under local anesthesia where the responses to cortical stimulation were carefully plotted. This marked also the first public appearance of the motor-sensory "homunculus" (Figure 3) (who later appeared in several different guises) and of the composite stimulation maps that have become so familiar from Penfield's publications over the years (Figure 4).

\section{Advent of Electroencephalography}

One of the many institute plaques identifies the opening of the EEG Laboratory in January 1939 (Figure 5). It names the generous Montreal citizens who matched the supplementary grant from the Rockefeller Foundation.

During the years, 1939-1945, the work at the Institute was focussed on solving many urgent war-time problems. A highlight in the story of epilepsy was the Penfield-Erickson monograph "Epilepsy and Cerebral Localization". ${ }^{8}$ Herbert Jasper's chapter provided the first comprehensive review of the application of EEG and corticography to the diagnosis and surgical treatment of epilepsy.

Publications by Penfield with Kristiansen, Rasmussen and others, continued to document the many detailed findings of the work at the Institute. 9,10

\section{Recognition of mesial temporal epilepsy}

From 1950 there developed a new approach in the surgical treatment of seizures, with the recognition of what is such a common problem today - temporal lobe epilepsy. The study by Earle, Baldwin and Penfield"l introduced the concept of mesial temporal sclerosis due to hemiation of the inner part of the temporal lobe over the tentorium during difficult birth.

In a concurrent series of studies in the operating room, localization of seizure discharge in the periamygdaloid region was identified as the site from which stimulation most often evoked features of automatism and amnesia, with characteristic corticographic findings. ${ }^{12,13}$ This argued for the importance of including the amygdala as part of the surgical excision, a strategy that has proved over the years to be successful in the relief of seizures. 14

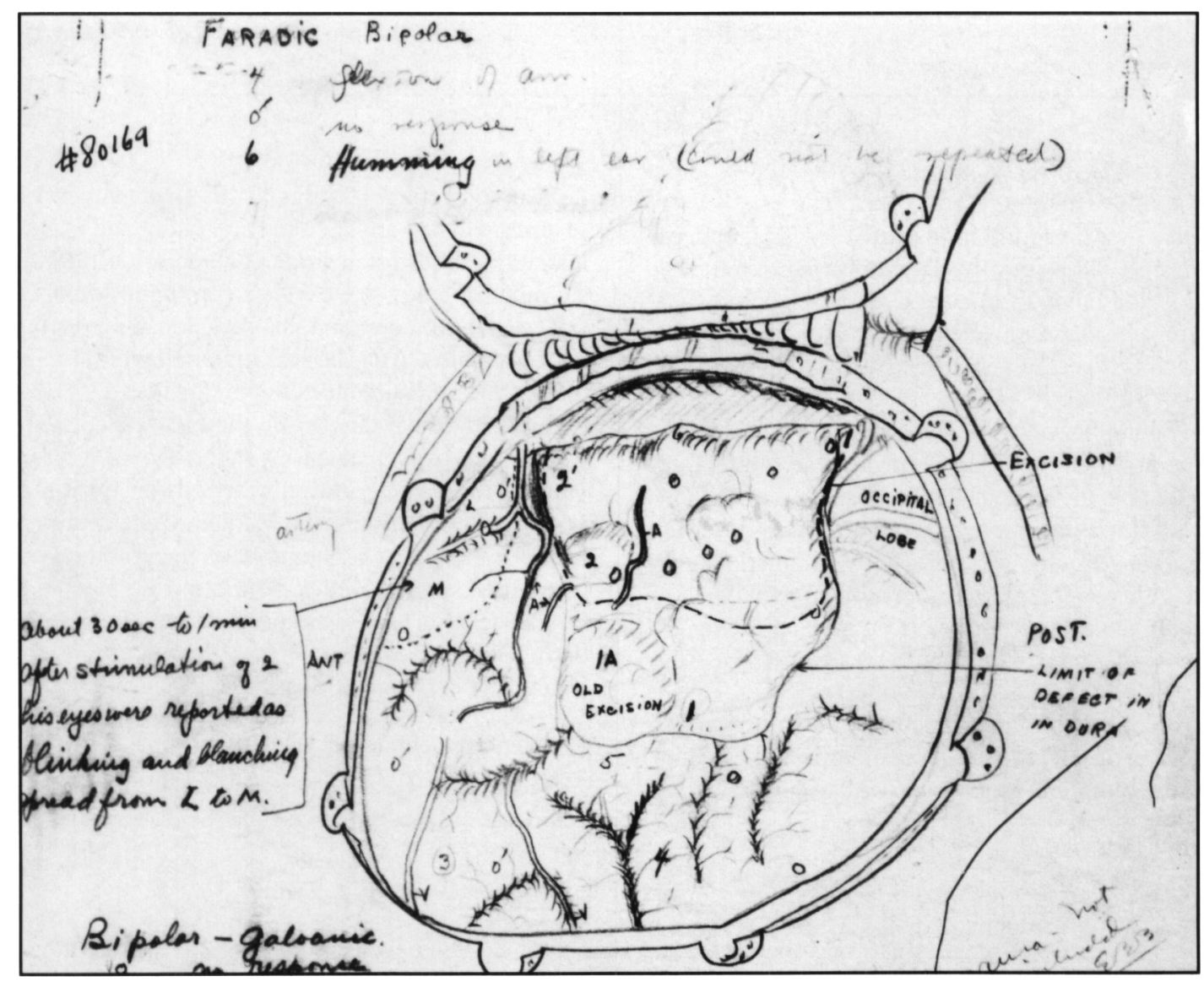

Figure I - Penfield's sketch and notes in patient R.M. showing the right side from the surgeon's view, upside down, with anterior to left, posterior to right. The excisions, outlined by dashed lines, included a small area in front of the motor cortex. (lA) and 3 years later removal of temporal lobe, outlined in the upper part of the drawing. 
The type of surgical approach to excision of the anterior and mesial part of the temporal lobe was reported and illustrated by Penfield and Baldwin. ${ }^{15}$ Among the first MNI trainees to go to the National Institute of Health at Bethesda, Baldwin became with Milton Shy, a key figure in the rapid expansion of that Institute's neurological section. They were joined during the 1950 's by some ten other young neuroscientists from the MNI who became the scientific core of that national institute.

In 1954, Penfield and Jasper ${ }^{16}$ published "Epilepsy and the Functional Anatomy of the Human Brain", a sequel, much expanded, to the Penfield-Erickson monograph. A wealth of other observations such as those relating to memory function by Penfield and Milner ${ }^{17}$ and on cortical localization of language by Penfield and Roberts, ${ }^{18}$ can only be sampled in this outline.

\section{Brain scanning in epilepsy}

Some prospect of the future research in epilepsy is provided by positron emission tomography (PET) of patients with epilepsy. This method gives a further indication for the selection of cases for surgery by demonstrating low glucose activity, oxygen usage and cerebral blood flow in the region of the epileptic EEG

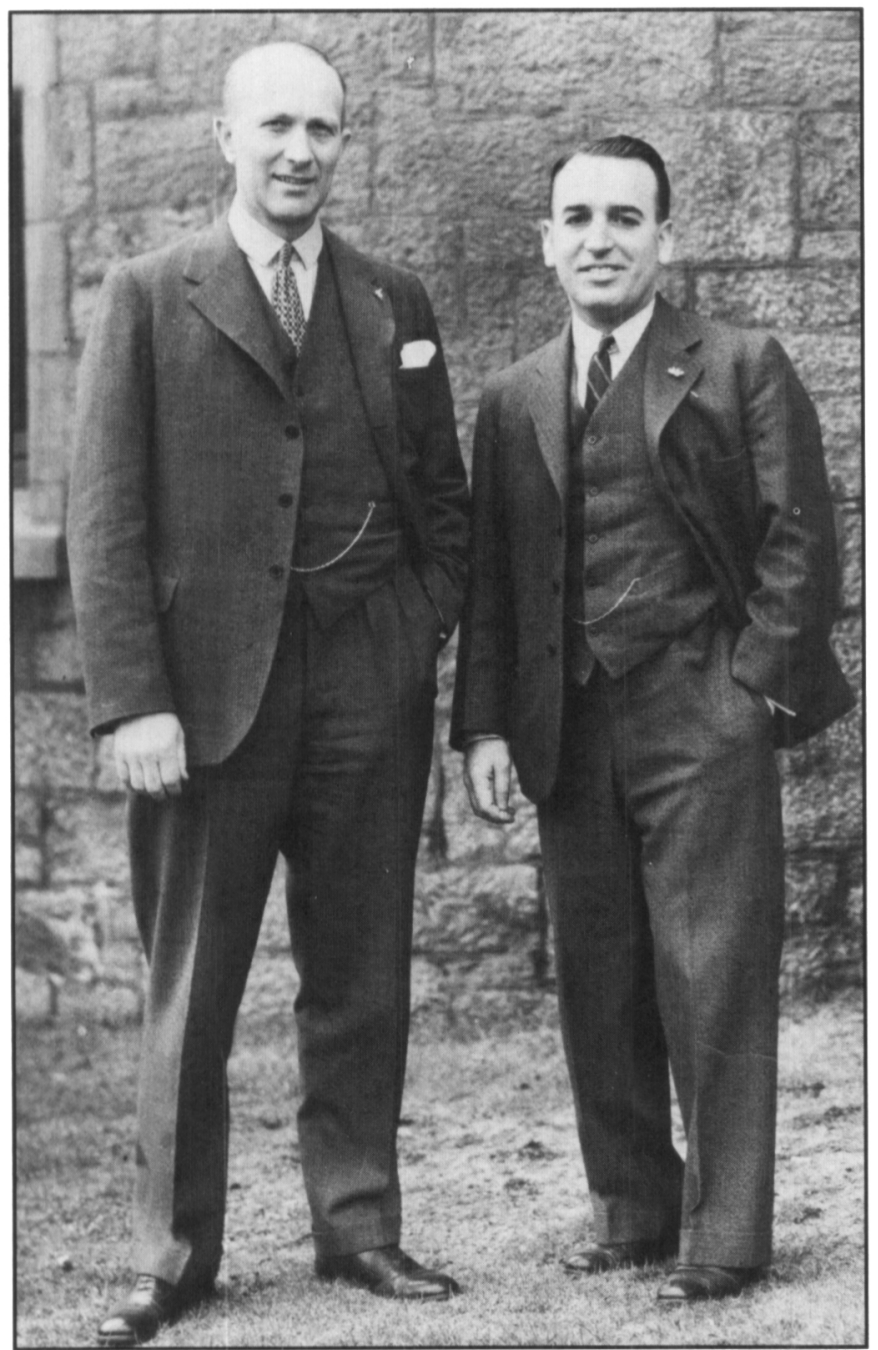

Figure 2 - Wilder Penfield and William Cone at the Royal Victoria Hospital (1932). activity, a finding, however, which still demands further elucidation. ${ }^{19-21}$ Diksic and Gjedde and others have also demonstrated an increased dopamine uptake in patients with temporal lobe epilepsy. These results represent an exciting approach by studies of neurotransmitter and receptor binding sites in the human epileptic brain. The elegant depth electrode studies of Olivier, Gloor and others have identified the exact sites for the responses from stimulation 22 in temporal lobe structures and implicated again the amygdala in experiential and autonomic responses.

In the past five years magnetic resonance imaging (MRI) has identified an increasing percentage of small pathological lesions, such as tumors or angiomas, in our patients with temporal lobe epilepsy. ${ }^{23}$ In addition, this technique has displayed in many patients an increase of signal intensity in the periamygdaloid region from which excised tissue commonly shows on microscopic examination gliosis and neuronal loss. ${ }^{24}$

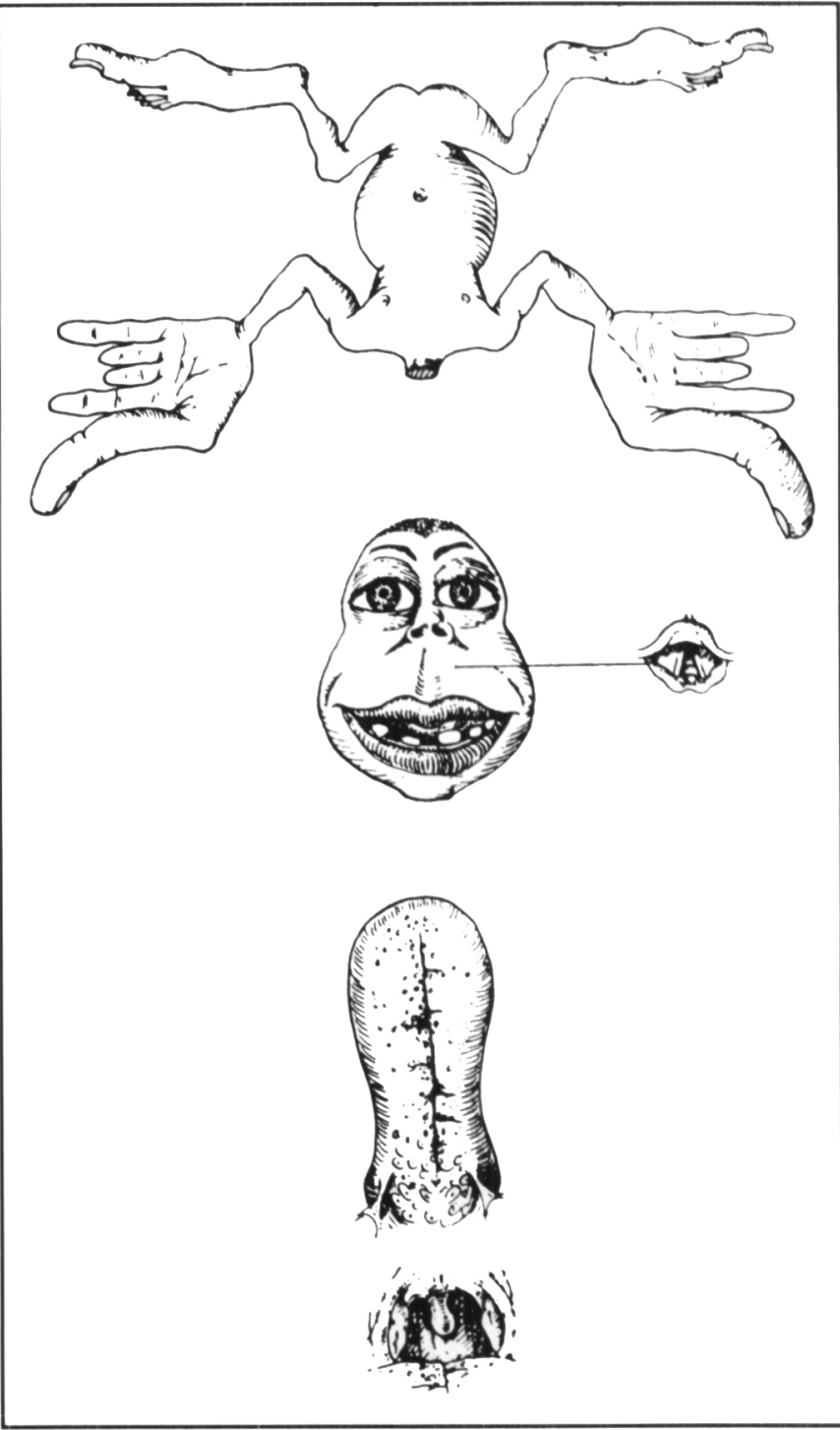

Figure 3-The "homunculus" depicting the areas of cortex relating to body movements as evoked by stimuiation of cortex (from Penfield and Boldrey, 1937). 


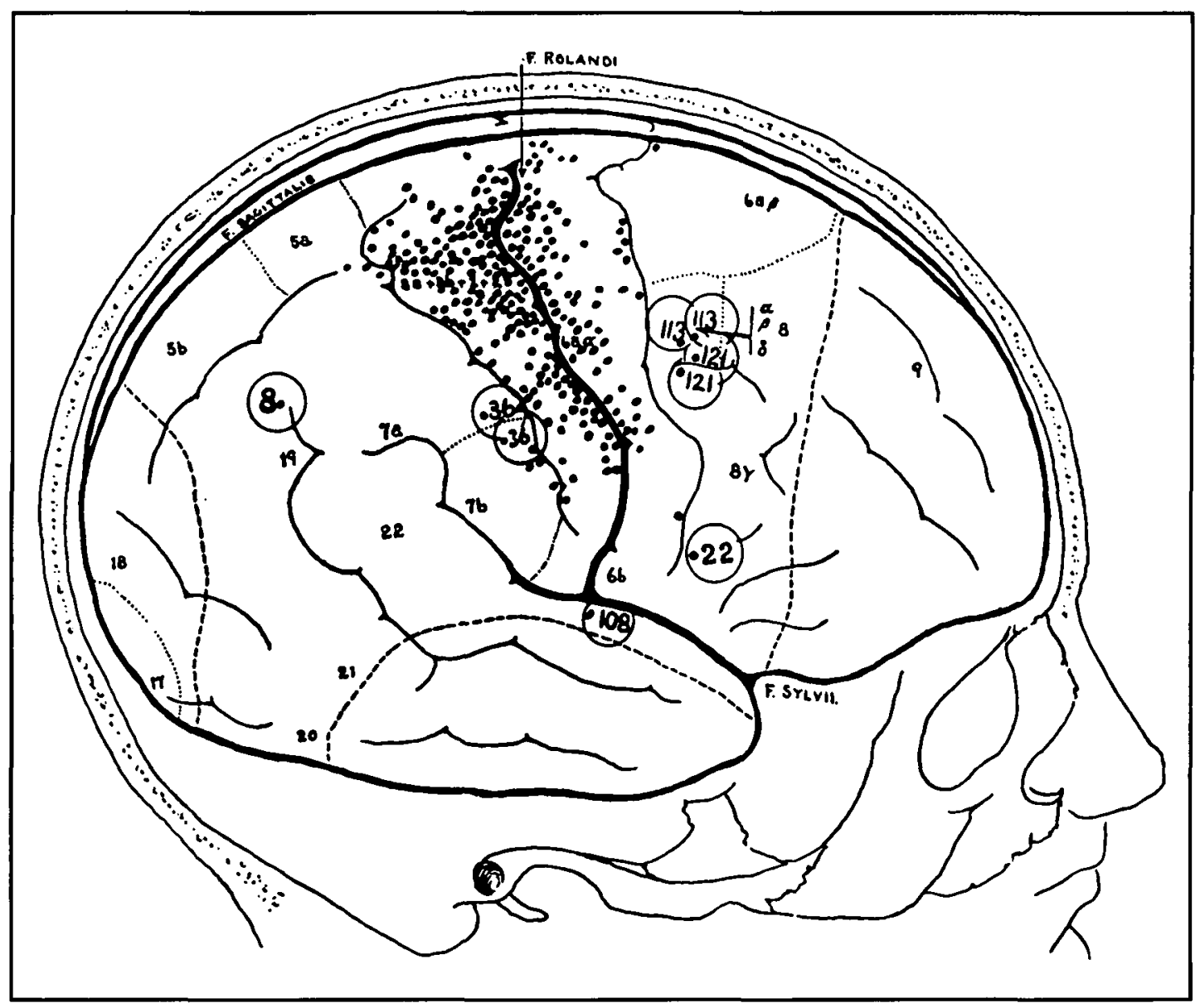

Figure 4-Map of composite motor and sensory responses from electrical stimulation of the cortex. (Penfield and Boldrey, 1937).

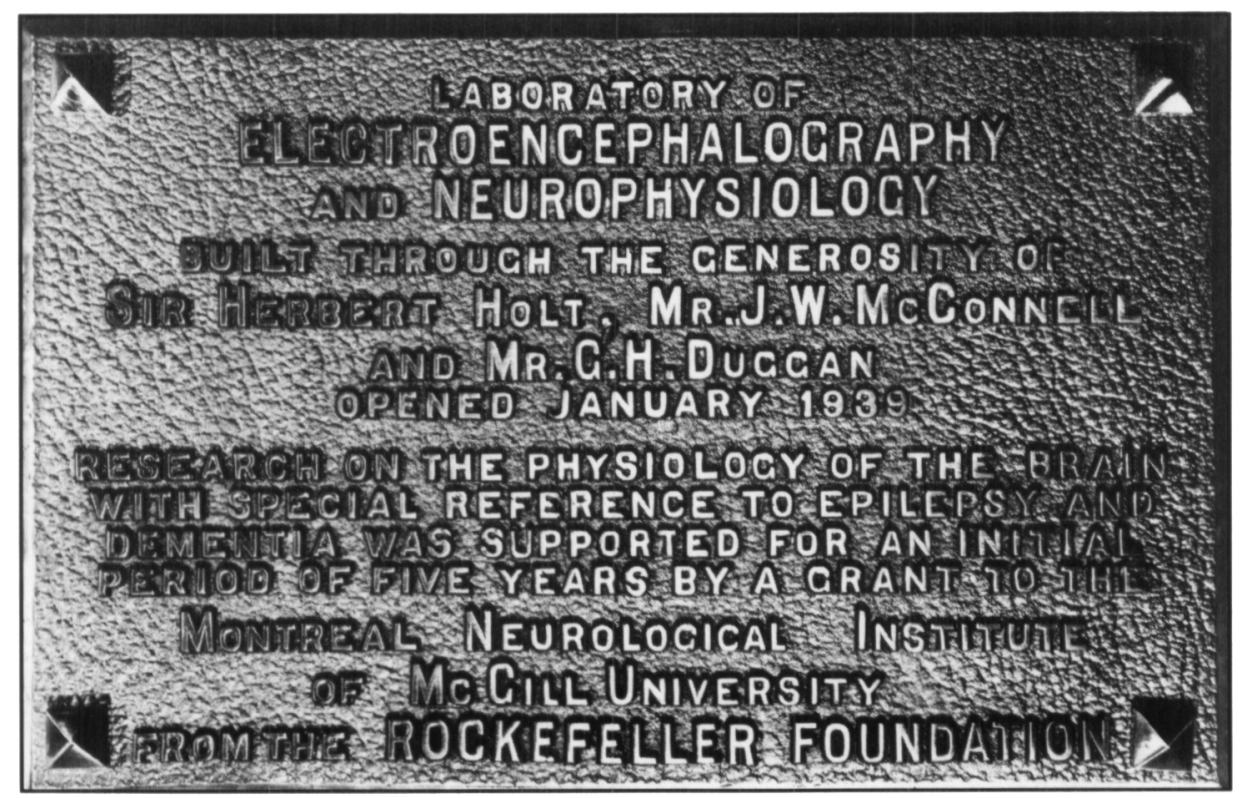

Figure 5 - Plaque to mark the opening in January, 1939 of the Laboratory of Electroencephalography and Neurophysiology with names of donors. 


\section{Team work: no man alone}

Many have contributed to this enterprise in the treatment of epilepsy at the Neurological Institute over the past fifty years; legions of physicians and researchers, residents and fellows, cohorts of nurses, technicians and support staff and many distinguished visiting scientists. Since 1945, the extraordinary talents of Charles Hodge and his team in neurophotography have made possible invaluable records of the operative findings, pathology, stimulation results and extent of the excision of the surgical cases which have enhanced our scientific reports and posters with elegance and clarity.

We mark with admiration and affection the patients who have undergone these procedures and who, we are gratified to report, have so often benefited from surgical treatment. The MNI now has a world series of over 3,000 patients who have been operated upon for focal excision of epileptogenic lesions. One of Rasmussen's meticulous long-term follow-up charts on cases who had temporal lobe removal shows that $65 \%$ had relief or nearly complete control of seizures while another $20 \%$ had significant reduction in seizures.

To paraphrase Dr. Penfield; certainly "no man alone" could have accomplished all this, but only many working together. We can all relish a great sense of satisfaction (though not of complacency) in the remarkable progress of the past half century here in EEG and neurophysiology. Begun by its eminent founder Herbert Jasper this work continues to flourish with an ever enlarging team under the direction of his outstanding students, Peter Gloor and Filipé Quesney. We salute them and thank them for their splendid contributions.

\section{ACKNOWLEDGEMENTS}

I am grateful to Theodore Rasmussen for identifying the first Montreal patient (RM) treated surgically for seizures by Wilder Penfield.

The work on this review was supported by grant No. 1-09-89 from the Donner Canadian Foundation, as part of a project to research and write the history of the Montreal Neurological Institute and Hospital (1934-1984).

\section{REFERENCES}

1. Foerster $O$, Penfield $W$. The structural basis of traumatic epilepsy and results of radical operation. Brain 1930; 53(II): 99-119.

2. Report of the Neurosurgical Service, Royal Victoria Hospital. 1930; Penfield Archive.

3. Penfield W, ed. Cytology and cellular pathology of the nervous system. (3 vols., 1267 pages) New York: Paul B. Hoeber, Inc., 1932.

4. Penfield $W$. The evidence for a cerebral vascular mechanism in epilepsy. Ann Intern Med Assoc 1933; 7(3): 303-310.

5. Penfield W. The circulation of the epileptic brain. Res Publ Assoc Res Nerv Ment Dis 1937; 18: 605-637.
6. Penfield W. Remarks on incomplete hypothesis for the control of cerebral circulation. J Neurosurg 1971; 35: 124-127.

7. Penfield W. Boldrey E. Somatic motor and sensory representation in the cerebral cortex of man as studied by electrical stimulation. Brain 1937; 60(IV): 389-443.

8. Penfield W, Erickson TC. Epilepsy and cerebral localization (632 pages). Springfield, Ill.: Charles C. Thomas, 1941.

9. Penfield W, Kristiansen K. Epileptic seizure pattems (104 pages). Springfield, Ill.: P. Charles C. Thomas; Oxford, England: Blackwell, 1951.

10. Penfield $W$, Rasmussen $T$. The cerebral cortex of man (468 pages). New York: The Macmillan Company, 1951.

11. Penfield W, Earle KM, Baldwin M. Incisural sclerosis and temporal lobe seizures produced by hippocampal herniation at birth. Arch Neurol Psychiatry 1953; 69: 17-42.

12. Feindel W, Penfield W, Jasper H. Localization of epileptic discharge in temporal lobe automatism. Trans Am Neurol Assoc 1952; 14-17.

13. Feindel W, Penfield W. Localization of epileptic discharge in temporal lobe automatism. Arch Neurol Psychiatry 1954; 72: 605630.

14. Feindel W, Rasmussen T. Temporal lobectomy with amygdalectomy and minimal hippocampal resection: review of 100 cases. (this supplement)

15. Penfield W, Baldwin M. Temporal lobe seizures and the technic of subtotal temporal lobectomy. Ann Surg 1952; 136(4): 625-634.

16. Penfield $W$, Jasper $H$. Epilepsy and the functional anatomy of the human brain (896 pages). Boston: Little, Brown and Company, 1954.

17. Penfield W, Milner B. Memory deficit produced by bilateral lesions in the hippocampal zone. Arch Neurol Psychiatry 1958; 79: 475497.

18. Penfield W, Roberts L. Speech and brain-mechanisms (286 pages). Princeton: Princeton University Press, 1959.

19. Feindel W, Gloor P, Yamamoto YL, et al. Correlation of EEG and topographic cerebral blood flow in epilepsy by positron emission tomography. In: Akimoto H, Kazamatsuri H, Seino M, Ward AA Jr., eds. Advances in Epileptology: XIII Epilepsy International Symposium. New York: Raven Press, 1982: 151-156.

20. Yamamoto YL, Ochs R, Gloor P, et al. Pattems of rCBF and focal energy metabolic changes in relation to electroencephalographic abnormality in the inter-ictal phase of partial epilepsy. In: BaldyMoulinier M, Ingvar DH, Meldrum BS, eds. Cerebral Flood Flow, Metabolism and Epilepsy. 1. Current Problems in Epilepsy. London: John Libbey, 1983; 51-62.

21. Yamamoto YL, Ochs R, Ammann W, et al. Changes of energy metabolism and regional cerebral blood flow studied by positron emission tomography in the interictal phase of partial epilepsy. Acta Neurochir 1984; Suppl 33: 35-46.

22. Gloor P, Olivier A, Quesney LF, et al. The role of the limbic system in experiential phenomena of temporal lobe epilepsy. Ann Neurol 1982; 12: 129-144.

23. Kuzniecky R, de la Sayette V, Ethier R, et al. Magnetic resonance imaging in temporal lobe epilepsy: pathology correlations. Ann Neurol 1987; 22: 341-347.

24. Feindel W, Robitaille Y, Tampieri D, et al. EEG, MRI and pathology in patients treated surgically for temporal lobe epilepsy. (this supplement) 